III

ROMANIZATION AND ITS LIMITS 
Kathryn Lomas - 9789004401655

Downloaded from Brill.com@4/26/2023 10:27:41AM via free access 


\section{FUNERARY EPIGRAPHY \\ AND THE IMPACT OF ROME IN ITALY \\ $\mathrm{By}$ \\ KATHRYN LOMAS}

The experience of Italy under Roman domination has often been regarded as fundamentally different from that of the provinces - partly because Italy was conquered much earlier than the rest of the Mediterranean, but also because it enjoyed a different and closer legal relationship with Rome. As the vast amount of research on cultural change has indicated, the impact of Rome on regions of Italy was no less dramatic than on the provinces, and the full implications of Roman domination for the people of Italy is still not fully understood. What is clear, is that Italy, throughout, remained intensely regionalised, with strong local cultural traditions which adapted to, and interacted with, the ruling power of Rome, but did not disappear. ${ }^{2}$ The processes which determined which aspects of local culture and society survived, which did not, and which aspects of Roman culture (itself constantly changing) were absorbed require further examination.

The funerary inscriptions of Italy are a particularly valuable resource, since they form the single largest body of surviving epigraphy, but they present methodological problems in their interpretation. In particular, inscriptions are all too frequently studied in isolation from form, location and iconography of the monuments themselves. ${ }^{3}$ This paper will examine case studies of funerary inscriptions from several different areas of Italy, with varying experiences of Roman conquest and domination, but will analyse these in the context of the location and iconography of the monuments on

1 This paper was prepared as part of the research project Developmental Literacy and the Establishment of State Identities in Early Italy, funded by the Arts and Humanities research Board. I would further like to thank the Soprintendenze per i Beni Archeologici del Veneto for permission to reproduce Figure 1, and the Soprintendenze per i Beni Archeologici di Napoli e Caserta for permission to reproduce Figures 2, 3 and 4.

2 N. Terrenato, 'The Romanisation of Italy: global acculturation or cultural bricolage?' in TRAC 97: Proceedings of the $7^{\text {th }}$ Theoretical Roman Archaeology Conference (Oxford 1997), 20-27; G. Woolf, Becoming Roman : the Origins of Provincial Civilization in Gaul (Cambridge 1998), 7-16.

3 G.J. Oliver, 'Introduction' in G.J. Oliver, ed., The Epigraphy of Death. Studies in the History and Society of Greece and Rome (Liverpool 2000), 12-15; V. Hope, 'Inscription and Sculpture: the construction of identity on the military tombstones of Roman Mainz', ibid., 155-86. 
which they were placed. It will focus on the period from the Social War to the end of the $1^{\text {st }}$ century $\mathrm{AD}$, a period which was one of extensive cultural change in Italy. Romanization is clearly an important issue throughout the post-conquest history of Italy. It is also a notoriously difficult and problematic concept to define. Neither Roman culture, nor any of those with which it interacted, were static and the nature of cultural interactions with Rome varied widely according to the local context, social status and possibly gender of the individuals concerned. In any study of interaction between Roman and non-Roman cultures, we can see a process of negotiation and manipulation as each party adopts, adapts or rejects different aspects of culture according to his/her own agenda and needs. The late Republic and early empire is an era of particularly radical change in Italian culture and society, and this is reflected in changes in epigraphic culture which can provide an important source of evidence for the processes of cultural change.

Research on the epigraphy of Italy in the period before and immediately after the Social War has increasingly highlighted the extent to which many regions had flourishing and distinct traditions of written commemoration which were entirely independent of that of Rome. ${ }^{4}$ These provide a rich source of evidence for the social structure, social interactions, political and religious cultures of pre-Roman Italy; equally, the manner and means by which they eventually faded and were superseded by a superficially homogenous 'Romanized' epigraphic culture, based around the use of Latin language and alphabet, can also be very revealing as a way into the impact of Rome on the various non-Roman cultures of Italy. It is becoming increasingly clear that the level of homogeneity may be merely superficial and there is considerable evidence that local epigraphic cultures and traditions remained strong even within the Latinized epigraphic culture of the $1^{\text {st }}$ century $\mathrm{AD}$ onwards. ${ }^{5}$

A useful model for the process of Romanization in funerary epigraphy has recently been constructed using a database of c. 4000 Etruscan and Latin

4 E. Benelli, Le iscrizioni bilingui etrusco-latine (Florence 1994); id. 'The Romanization of Italy through the epigraphic record' in S. Keay and N. Terrenato, eds., Italy and the West: Comparative Issues in Romanization (Oxford 2001), 8-10; R. Häussler, 'Writing Latin from resistance to assimilation: language, culture and society in N. Italy and S. Gaul' in A. Cooley, ed., Becoming Roman, Writing Latin. Literacy and Epigraphy in the Roman West (Portsmouth RI 2002), 61-75.

5 Häussler 2002, op. cit. (n 4), 72-4; P. Milnes-Smith, "'Lapidarias litteras scio". Literacy and inscribing communities in Roman Venetia', in K. Lomas, R. Whitehouse and J. Wilkins, eds., Literacy and Establishment of State Societies (London, forthcoming). 
inscriptions from nothern Etruria - specifically, the territories of Perugia, Arezzo and Chiusi. ${ }^{6}$ Each inscription is subdivided into a series of potential cultural indicators, charting the elements of Roman culture adopted by the local population and examining how these were used. The pattern revealed is one of a complex interaction, in which certain aspects of Roman culture were adopted relatively early, while in other areas, the region retained a very high degree of pre-Roman cultural practices until much later. The inscriptions were analysed for the script and language, the content and form of the personal names, and the general epigraphic formulae and format used. Changes in these indicators over time were examined, then the varying patterns were brought together to give an overview of the epigraphic culture of the region in the $2^{\text {nd }}-1^{\text {st }}$ centuries $\mathrm{BC}$ and $1^{\text {st }}$ century $\mathrm{AD}$, and in particular the so-called private responses to Rome reflected in funerary inscriptions. ${ }^{7}$ The same methodology has also been applied to the epigraphy of north-east Italy, but other regions of Italy were excluded-notably those where the preRoman epigraphic habit is Greek or exposed to a high degree of Hellenisation - on the grounds that these areas are atypical and would skew the analysis. ${ }^{8}$ While it is undoubtedly true that the Greek language had a higher status than many others in the eyes of the Roman elite of the late Republic and early Empire, this is not a reason to dismiss evidence from the Greek or Hellenised areas of Italy out of hand. If interaction with Rome, and Roman culture, is to be understood as a process of dialogue and mutual interaction between cultures which are themselves not static, there is no good reason to omit a group, or groups, because a small - if influential - sector of Roman society might react to its culture in a particular way. In any case, the attitude of Romans to Greeks and the Greek language was highly ambivalent and the Greek culture of the region concerned itself raises some complicated cultural issues. ${ }^{9}$ The aim of this paper, therefore, is twofold: firstly, to apply Benelli's

6 Benelli 1994 and 2001, opp. citt. (n. 4).

7 On the dichotomy between public and private in the ancient world and the difficulties in defining it, see P. Veyne, 'The Roman empire' in P. Veyne, ed., A History of Private Life. Vol.1 (Cambridge, Mass., 1987), 161-71. The differences in practice between public and private spheres in epigraphy are discussed by Häussler, 'Writing Latin - from resistance to assimilation', 72-4 and Benelli, 'La romanizzazione attraverso l'epigraphfia: Il Veneto e il modello Etrusco' in O. Paoletti, ed., Protostoria e storia del 'Venetorum Angulus' : atti del XX Convegno di studi etruschi ed italici (Pisa and Rome 1999), 654-7, and Benelli 2001, op. cit. (n. 4), 10-11.

8 Benelli 2001, op. cit. (n. 4), 1-8

9 J. Kaimio, The Romans and the Greek Language (Helsinki 1979); E. Gruen, Studies in Greek Culture and Roman Policy (Leiden 1990), 170-74; id., Culture and National Identity 
methodology to data from selected Greek areas of Italy and compare the results with his findings from Etruria and North East Italy, and secondly, to try to place some of the inscriptions concerned in context by examining the form and iconography of the monuments on which they were written, as well as the cultural content of the inscriptions themselves. By adopting this twopronged approach, it may be possible to shed some further light on the impact of Rome on local cultures and the reaction of those cultures to Roman cultural influence.

\section{The 'Benelli model' and the Romanization of Etruria}

The general pattern of funerary inscriptions in northern Etruria is one of considerably mixed cultural signals during the $1^{\text {st }}$ century $\mathrm{BC}$ and into the early $1^{\text {st }}$ century $\mathrm{AD}$. In Benelli's analysis, it shows some interesting divergences between the language, form and content of the inscriptions (Table 1). Before c. 100 BC, Etruscan language and culture predominates. The majority of funerary inscriptions were written in Etruscan language and script, using Etruscan names and Etruscan epigraphic forms and formulae. Latin funerary inscriptions are also found, but these are a small minority of the total sample of c. 4000 texts. ${ }^{10}$ By the middle of the $1^{\text {st }}$ century BC, many - if not most inscriptions still use Etruscan language and funerary formulae, but Latin influences are becoming stronger, and some texts which are Etruscan in content - i.e. using Etruscan names, onomastic forms and funerary formulae are written in Latin script. More Latin names are finding their way into the onomastic traditions of the region, but at the same time, names (even Latin ones) are mostly expressed in Etruscan form. In some cases, Etruscan and Latin names and onomastic forms co-exist in the same family. ${ }^{11}$ By the second half of the century, Latin is becoming more widespread, the use of Roman (or Romanized) names and onomastic forms is spreading and Etruscan inscriptions are restricted to increasingly small areas, but there are still substantial traces of Etruscan names, name-forms and funerary formulae to be found. Nor is the process a linear, one-way, change. Benelli cites the example of T. Pontius Rufus of Chiusi, who used the Roman tria nomina,

in Republican Rome (London 1993), 227-70; K. Lomas, Rome and the Western Greeks. Conquest and Acculturation in Southern Italy (London 1993), 161-68 and 174-87.

${ }^{10}$ Benelli 1994, op. cit. (n. 4), 62-66; id. 1999, op. cit. (n. 7), 654-8.

"For instance, the family of T. Pontius Rufus, of Chiusi, a Roman immigrant who intermarried with the local family of the Cezrtle, and whose descendants re-adopted Etruscan for their epitaphs: H. Rix, Die Etruskischen Texte. Editio Minor, 2 vols. (Tübingen 1991), Cl. 1.919; Benelli 1994, op. cit. (n. 4), 63, and id. 1999: 655-5. 
but whose descendants reverted to Etruscan names. ${ }^{12}$ Latin language and script, and Roman names and funerary formulae do not become fully dominant until the beginning of the $1^{\text {st }}$ century $\mathrm{AD}$. Thus we have a pattern where for a period of c.50 years or more, inscriptions written in Latin may be almost entirely Etruscan in terms of content, and different members of the same family may swap between Roman and Etruscan cultural indicators.

\section{North-East Italy}

Benelli's other detailed regional case-study, north-east Italy, is similar to Etruria in some ways, but also shows some important and significant differences. ${ }^{13}$ Like Etruria, it has a strong tradition of literacy. The earliest inscriptions appear in the late $7^{\text {th }}$ century $\mathrm{BC}$, and inscriptions in the most widespread of the local languages, Venetic, persist until the $1^{\text {st }}$ century $\mathrm{BC}$, well after the Social War. ${ }^{14}$ The vast majority are either funerary inscriptions or votives, with a small number of possible public inscriptions, inscriptions on small personal artefacts such as jewellery, and stamps on pottery and amphorae. The numbers are considerably smaller than those of inscriptions from Etruria - c. 750 all told, of which c. 270 are funerary - most of which come from two particular cemeteries at Este, from Altino, or from Padua. ${ }^{15}$

${ }^{12}$ Benelli 2001, op. cit. (n. 4), 10-12; id. 1994, op. cit. (n. 4), 63; Rix 1991, op. cit. (n. 11), Cl. 1.919 .

${ }^{13}$ Benelli 1999, op. cit. (n. 7), 654-8.

14 A.L. Prosdocimi, 'Una iscrizione inedita dal territorio atestino. Nuovi aspetti epigrafici linguistici culturali dell'area paleoveneta', in Atti dell'Istituto Veneto di scienze lettere ed arti, classe di scienze morali e lettere 127 (1968-69), 123-183; L. Calzavara Capuis, 'Rapporti culturali veneto-etruschi nella prima età del Ferro' in R. de Marinis, ed., Etruschi a nord del Po (Udine 1988), 90-102; AAVV, Akeo, I tempi della scrittura (Montebelluna 2003), 157-8. For the development and adoption of the alphabet, see M. Pandolfini and A.L. Prosdocimi, Alfabetari dell'Italia antica (Florence 1990). Inscriptions in Venetic are collected in G.B. Pellegrini and A.L. Prosdocimi, La Lingua Venetica (Padua 1967) and those in Raetic by S. Schumacher, Die Rätischen Inscriften. Geschichte und heutiger Stand der Forschung (Innsbruck 1992). The most recent review of the evidence for literacy in the Veneto is in AAVV, Akeo. I tempi della scrittura.

${ }^{15}$ For the typology of Venetic inscriptions, see AAVV, Akeo I tempi della scrittura (n. 14); on the inscriptions from Este, see Pellegrini and Prosdocimi 1967, op. cit. (n. 14), 193-283, 344-48, 409-26; A. Marinetti, 'Este preromana. Epigrafia e lingua' in G. Tosi, ed., Este antica: dalla preistoria all'età romana (Padua 1992), 125-72. For Venetic cemeteries, see L. Calzavara Capuis and M. Chieco Bianchi, Este. Le necropoli Casa di Ricovero, Casa Muletti Prosdocimi e Casa Alfonsi (Rome 1995); A. Marinetti, 'Gli apporti epigrafici e linguistici di Altino preromana' in G. Cresci Marrone and M. Tirelli, eds., Vigilia di romanizzazione. Altino e il Veneto orientale tra II e I sec. a.C. (Rome 1999), 75-95. 
The data shows a pattern broadly similar to that from Etruria (Table 2). There is an initial phase in which there is very little Latin influence, an intermediate phase in which Latin script is adopted but the language, names and form of the inscriptions is still largely local, and a final phase in which Latin names and epigraphic formulae are more widely adopted. ${ }^{16}$ There are more problems with this than with the Etruscan example, not least because the number of inscriptions is smaller, the material is more highly concentrated into a small number of sites, and the chronology is more difficult to finetune. The epigraphic culture of the Veneto is also very localised, which makes it more difficult to create a generic model for cultural interactions in funerary monuments. The types of funerary monuments and inscriptions found at Este are very different from those from neighbouring Padua and Vicenza, and the epigraphic culture of the lowland Veneto is distinct from that of the Italian Alps. ${ }^{17}$ Most of the inscriptions analysed by Benelli are from only two sites - the Casa di Ricovero and Villa Benvenuti cemeteries at Este. They are simple in form, consisting only of a personal name written in either Venetic or Latin and are inscribed, usually before firing, onto the pottery urns. These were used as containers for cremated remains and deposited in graves along with other grave goods. ${ }^{18}$ These appear to be the main form of commemoration, and most graves do not have any obvious sign of an external grave marker.

So far, this might support Benelli's thesis that local names and nameforms were more likely to be used in so-called 'private' contexts such as funerary inscriptions designed to be deposited in tombs rather than placed on full public display. However, there is other evidence which may problematise this. One grave marker in particular is worth examining in detail since it is one of the few from this region with allows us to consider a funerary

\footnotetext{
${ }^{16}$ Benelli 1999, op. cit. (n. 7), 655-64.

${ }^{17}$ The differences in alphabet, letter-forms and votive formulae between the northern and southern Veneto are highlighted in A. Marinetti, 'Il venetico di Lagole' in G. Fogolari, and G. Gambacurta, eds., Materiali veneti preromani e romani del santuario di Lagole di Calalzo al Museo di Pieve di Cadore (Rome 2001), 61-72, and in K. Lomas, 'Writing and Reita. The development of literacy in north-east Italy', in Lomas, Whitehouse and Wilkins, op. cit. (n. 5).

${ }^{18}$ For instance, 'Fugia Muskialnai' (Pellegrini and Prosdocimi 1967, op. cit. (n. 14), Es86) and 'Moloto Ennonia' (ibid., Es90), both epitaphs of funerary urns from the cemetery at Casa di Ricovero at Este; for a full discussion, see Marinetti 1992, op. cit. (n. 15), 333-55 (inscriptions) and C. Balista and A. Ruta Serafini, 'Este preromana. Nuovi dati sulle necropoli', in Tosi 1992, op. cit. (n. 15), 112-123 (cemeteries).
} 
inscription in the context of iconography. ${ }^{19}$ This is a rectangular stele of local limestone, found on the Via Massimo in the centre of Padua in 1962, and dating to the late $1^{\text {st }}$ century BC (Fig. 1). On the upper section of the stele is a square panel containing a relief sculpture, with a reserved border around all four sides. About $30 \%$ of the stele is undecorated and unworked and it was almost certainly intended to be set into the ground. The inscription runs round the top and right-hand border of the stele. Both the figurative decoration, the inscription and the general type of the monument show an interesting mixture of cultural elements. The scene shows a biga galloping from right to left, carrying a charioteer and two passengers. The general type of the monument, and the scene represented, is found on other examples dating to the $6^{\text {th }}-2^{\text {nd }}$ centuries $\mathrm{BC}$, and may represent the journey of the dead to the underworld. The details, however, indicate a continuing co-existence of Roman and Venetic culture. The male figure is draped in a toga, the characteristic dress of a Roman citizen. The female figure, in contrast, wears local Venetic costume consisting of a long-sleeved, full-skirted dress and cloak pinned in the centre of the body. She also appears to have a head-dress surmounted with a disk, another local feature which is found on other earlier stelai of the same sequence from Padua. The iconography therefore alludes to Roman status, but for the man only, while the representation of the woman and the overall cultural framework are drawn from traditional Venetic funerary monuments of the area. The inscription, which reads ' $[M$ '. Gallen]i M'.F. Ostialae Galleniae equpetars' ('Monument to Manius Gallenius, son of Manius, and Ostiala Gallenia') shows a similar mixture of cultural signals. It is written in the Latin alphabet and uses a Romanised name-form for the man - M' Gallenius, M'.F. - but the name of his wife Ostiala Gallenia - is certainly Venetic in content and probably in form. The use of the praenomen in female names is unusual in Roman onomastics but is well-attested in the Veneto, and the praenomen itself - Ostiala - is derived from a name which is very common in this area. ${ }^{20}$ The formula of the inscription is also Venetic, using a Latinised form of the formula 'ekupetaris

${ }^{19}$ A. Prosdocimi, 'Una stele paleoveneta patavina di epoca romana', Atti e Memorie dell'Accademia Patavina 77 (1964-65), 19-30; Pellegrini and Prosdocimi 1967, op. cit. (n. 14) Pa6; G. Fogolari, 'La cultura' in G. Fogolari and A.L. Prosdocimi, eds., I Veneti antichi (Padua 1988), 99-105.

20 J. Untermann, Die venetischen Personennamen (Wiesbaden 1961), 117-9; Pellegrini and Prosdocimi 1967, op. cit. (n. 14), 148-50. 
ego' which is found on the earlier grave stelai from Padua. ${ }^{21}$ So far, the addition of iconography to the equation seems to confirm Benelli's thesis that Roman practice was a fairly thin veneer, and selectively applied, for some considerable length of time, although in this instance we seem to be considering a monument which may have been for public display, not for burial in a tomb or some other 'private' context. The other difficulty we face is that it is a unique example. Nevertheless, it provides a useful illustration of the cultural complexities of the late $1^{\text {st }}$ century BC, and an example of how one particular family attempted to weave the various cultural strands together.

\section{Greek inscriptions: Ancona and Naples}

The largest concentration of Greek inscriptions from the period post-dating the Roman conquest of southern Italy is found at Naples. Other sites, notably Velia and Rhegium, also have some Greek inscriptions of similar date, and there is an important group of Greek funerary monuments from Ancona. This paper will concentrate on material from Ancona and Naples, but the general pattern shown by the funerary inscriptions from other Greek communities is broadly consistent with the results from these two cities. These communities all have a generically Greek ethnic and cultural background but do not form a geographical unit. Their relations with Rome also varied. Naples was a long-standing ally, having negotiated a highly favourable treaty with Rome in 325 BC (Livy 8.22-27; Dionysius of Halicarnassus, Antiquitates Romanae 15.5.5-9.2), while Ancona also entered into Rome's orbit during the $3^{\text {rd }}$ century $\mathrm{BC}$, in circumstances which are less clear (Livy 10.44.8-45.11).

If the funerary inscriptions from these communities are analysed using the criteria developed by Benelli (Table 3), it is immediately apparent that there is much less overlap between the Greek and non-Greek epigraphic habit in these communities than there is in Etruria and the Veneto. At Ancona, for instance, there are relatively few Greek funerary inscriptions from the $1^{\text {st }}$ century $\mathrm{BC}$ or $1^{\text {st }}$ century AD. Those which do date to the early-mid $1^{\text {st }}$ century $\mathrm{BC}$ are for the most part written in Greek, with little interference

${ }^{21}$ Cf Pellegrini and Prosdocimi 1967, op. cit. (n. 14), Pa1-Pa5; A.L. Prosdocimi, 'La Lingua', in Fogolari and Prosdocimi 1988, op. cit. (n. 19), Pa24. The exact meaning of 'ekupetaris' (sometimes also 'eppetaris' or 'ekvopetars') is obscure. It is possible that it is an indicator or social rank or status, but the most usually accepted interpretation is that it refers to the grave marker itself - i.e. 'I am the monument of ...'). 
from Latin/Roman language, names or epigraphic forms. ${ }^{22}$ By the $1^{\text {st }}$ century $\mathrm{AD}$, most funerary inscriptions have made the transition to Latin. A similar pattern is evident at Rhegium and Velia, but these communities still retain Greek as a written language for other public documents. Greek remains in use for civic inscriptions - which include decrees of the city council, honorific inscriptions, building inscriptions etc. - and inscriptions connected with cults until well into the $2^{\text {nd }}$ century $\mathrm{AD} .^{23}$

Ancona represents an unusually complex case of cultural interaction. It was originally a Picene settlement which was the site of a Syracusan colony that was founded in the $4^{\text {th }}$ century BC (Strabo, Geography 5.4.2). It came under Roman control in $3^{\text {rd }}$ century $\mathrm{BC}$ and further colonists were added to the city by Rome in the Augustan period (Caesar, Bellum Civile 1.11; Appian, Bella Civilia 5.23). An interesting group of 15 Greek funerary stelai survives, dating from the late $2^{\text {nd }}$ century $\mathrm{BC}$ to the early $1^{\text {st }}$ century $\mathrm{BC}$, well after the date at which Ancona came under Roman influence. ${ }^{24}$ The stelai as a group are associated with an area of wealthy burials containing local and imported pottery, amphorae with Greek stamps, glass, strigils, and jewellery, some of it gold. ${ }^{25}$ Unfortunately, the exact contexts are lost and they cannot be associated with specific graves. The stelai are of a typical Greek type marble, with architectonic surround (either pillars and a pediment or a niche) containing a scene in relief sculpture depicting the deceased. Most represent a dexiosis - a farewell between the deceased and his/her relatives - or a banquet scene in which the deceased reclines on a couch. Both of these are typical Greek funerary types, and carry inscriptions in Greek, identifying the deceased by Greek names, given in Greek forms and using the typical Greek formula 'chaire'or 'chreste chaire'. ${ }^{26}$ The women depicted are represented wearing Greek dress, and some are veiled. However, there are also signiicant traces of Roman cultural features. Several male figures are represented wearing Roman dress, the toga exigua which was the badge of Roman

${ }^{22}$ E.g. Symmache Sopatrou, Gaulion Diodorou, Apollonie Apollon[iou] (all cited by L. Mercandi 'L'ellenismo nel piceno' in P. Zanker, ed., Hellenismus in Mittelitalien, vol. I (Göttingen 1976), 161-72.

${ }^{23}$ Lomas 1993, op. cit. (n. 9), 174-85.

24 Mercandi 1976, op. cit. (n. 22), 161-72; F. Colivicchi, 'Dal pallium alla toga: Ancona fra ellenismo e romanizzazione', Ostraka 9.1 (2000), 135-42.

${ }^{25}$ Mercandi 1976, op. cit. (n. 22), 164-70.

${ }^{26}$ For example, 'Damo chreste chaire' and 'Apollonie Pasionos chreste chaire'. Mercandi, op. cit., 164-70, Colivicchi 2000, op. cit. (n. 24), 136, 139 and figs. 1a and 5. 
citizenship. ${ }^{27}$ Clearly there was still a strong strand of local Hellenised culture in the elite of $1^{\text {st }}$ century BC Ancona, but also recognition of the need to adopt some of the symbols of Romanitas. Ambiguities about the general culture of Ancona make this particular group of stelai difficult to interpret. A recent study of this group of inscriptions argues that Ancona was never a fully Greek community, and that Hellenism in Ancona was the preserve of a relatively small number of families which did not integrate fully with what remained essentially a Picene, then a Roman, community. ${ }^{28}$

The final example, Naples, is a very different case. This was also a multicultural community, with a substantial Campanian minority and possibly some Etruscan population as well. It was a notably loyal ally of Rome and was much favoured by the Roman elite for its Greek culture. ${ }^{29}$ The Neapolitans had good reason to go out of their way to maintain their Greek identity as it brought them recognition and favour. However, the epigraphic habits of the city show a more complex story. As with other Greek communities, public documents - decrees, honorific inscriptions, high-profile cult inscriptions etc - are written in Greek. ${ }^{30}$ Funerary inscriptions, however, are much more mixed (Table 4). The chronology of cultural change is later than that of Etruria and the Veneto, with Greek inscriptions persisting in substantial numbers well into the $1^{\text {st }}$ century $\mathrm{AD}$ and even into the $2^{\text {nd }}$ century, although by this time they are in a minority. Unlike the Etruscan and Venetic texts, which include examples where Latin is used as a vehicle for otherwise local inscriptions, Latin is never used to express Greek types of funerary formula or Greek name-forms. However, the reverse process, by which Greek is used as a medium for literal translations of Latin funerary forms such as the $\mathrm{D}$ (is) $\mathrm{M}$ (anibus) inscription, is well-documented. ${ }^{31}$ Roman or Italic names continue to be used alongside Greek ones in substantial quantity throughout the $1^{\text {st }}$ century $\mathrm{BC}$ and $1^{\text {st }}$ century $\mathrm{AD}$, but the standard Greek

${ }^{27}$ Colivicchi 2000, op, cit., 137-9.

${ }^{28}$ Colivicchi 2000, op. cit., 139-42.

${ }^{29}$ Dio Cassius 55.10.9-10; Strabo, Geography 5.4.7; K. Lomas, 'Graeca urbs? Ethnicity and culture in early imperial Naples', Accordia Research Papers 7 (1997-98), 125-7; M. Leiwo, Neapolitana. A Study of Population and Language in Graeco-Roman Naples (Helsinki 1994), 29-32.

${ }^{30}$ E. Miranda, Iscrizioni greche d'Italia. Napoli I (Rome 1990); Lomas 1993, op. cit. (n. 9), 176-81.

${ }^{31}$ The epitaphs of Novia Hermione, Hermes and Perpetua (IG 14, 802), which date to the $2^{\text {nd }}$ century $\mathrm{AD}$, are a clear example of this phenomenon. The epitaph is written in Greek, but the funerary formulae (including the invocation to the Dis Manius) are of Latin type, translated literally into Greek. 
onomastic form of name + patronymic is preferred by the majority to the Roman tria nomina until well into the $1^{\text {st }}$ century $\mathrm{AD} .{ }^{32}$ Where Roman names occur, either in Greek or Latin inscriptions, they are mostly given in the form nomen + cognomen rather than as a proper Roman tria nomina. By the $2^{\text {nd }}$ century, however, Greek starts to disappear, and the majority of socially-significant individuals use Latin for their epitaphs. Greek, in contrast, is increasingly associated with low-status catacomb burials. ${ }^{33}$

A group of marble stelai dating from the early $1^{\text {st }}$ century $\mathrm{BC}$ to the mid $1^{\text {st }}$ century $\mathrm{AD}$ is particularly informative. Like the Ancona stelai, they are carved in relief with a naiskos containing a dexiosis scene of the deceased bidding farewell to a friend or relative - a well-documented Greek type of funerary monument (Figs. 2-4). ${ }^{34}$ Also like the Ancona stelai, they carry exclusively Greek inscriptions, using Greek funerary formulae. However, both the iconography and the personal names reflect the cultural complexity of the era. Most - although not all - the names are given in Greek form, but some are not of Greek origin. For instance, Grania Felicla and Gaius Valerius ${ }^{35}$ have completely Romanised names, while Ariston, Aste and Lamiskos Lamiskou (Fig. 3 ) $^{36}$ have Greek ones, and Mamos Mamou and Leukios Larthios (Fig. 4) ${ }^{37}$ have names which are Greek in form but not in content - one being Oscan and the other being a mixture of Latin and Etruscan. In addition, some of the women are depicted seated on the high-backed chair characteristic of the Roman matrona (Fig. 2) and some of the men are depicted togate (Fig. 3) while others are depicted in Greek dress

\footnotetext{
${ }^{32}$ For example, Bibie Archippou ( $1^{\text {st }}$ century BC; Leiwo 1994, op. cit. (n. 29), 82-3), Soteriche Soterichou (Leiwo, Neapolitana, 77-78), Loukia Nymphiou (Leiwo, op. cit., 84).

${ }^{33}$ The largest single group was found in the catacombs of S. Ianuarius, published as IG 14, 826.

${ }^{34}$ Leiwo, op. cit., 116-119; J. Papadopoulos, 'I rilievi funerari' in AAVV, Napoli Antica (Naples 1985), 293-8 and 294-7; K. Lomas, 'Personal identity and Romanisation: Greek funerary inscriptions from southern Italy', in E. Herring and J. Wilkins, eds., Inhabiting Symbols: Symbol and Imagery in the Ancient Mediterranean (London 2003), 197-207.

${ }^{35}$ IG 14, 774; Papadopoulos, 'I rilievi funerari', 296; E. Miranda, Iscrizioni greche d'Italia. Napoli II (Rome 1995), 36-7; Leiwo, op. cit., 120.

36 IG 14, 769, IG 14, 770 and IG 14, 796; Papadopoulos 1985, op. cit. (n. 34), 295-7; Miranda 1995, op. cit. (n. 35), 30-33 and 60-62.

37 G.A. Galante, 'Il sepolcro ritrovato in Napoli sotto il palazzo Di Donato in via Cristallini ai Vergini', Atti della Accademia di Scienze Morali e Politiche della Società Nazionale di Scienze, Lettere ed Arti di Napoli 17 (1893-96), 5-24; Papadopoulos 1985, op. cit. (n. 34), 295-6; Leiwo 1994, op. cit. (n. 29), 74-6 and 117-8; Miranda 1995, op. cit. (n. 35), 63-7.
} 
(Fig. 4). Nor is there any obvious chronological pattern in this; there appears to be a set of mixed cultural signals throughout this group of stelai.

\section{Conclusions: Funerary monuments and cultural change}

The pattern revealed in the Greek regions of Italy is therefore different from that of Etruria and the Veneto, but not uniform across the whole of Greek Italy. There are considerable similarities, but also some important differences between regions and individual communities in the way that they interact with Rome and the ways in which this is expressed in funerary art and commemoration. The variations between Greek and non-Greek regions are also fairly subtle - clearly they interacted differently with Rome, but are not wildly divergent from the model developed for Etruria. For instance, there is a longer chronology for Naples - the one site for which we have a large amount of evidence - with Greek persisting well into the Principate, but shifting in social value, eventually being abandoned by the elite and becoming a largely non-elite (or even slave) phenomenon. The form of personal names also remains fairly resistant to Roman influence, with a high proportion retaining a Greek form even after the adoption of Roman onomastics as individual elements of the name. In high-status public documents such as decrees of the boule, most personal names are, by the end of the $1^{\text {st }}$ century $\mathrm{AD}$, composed of Roman elements but still expressed in Greek form rather than using the structure of the tria nomina. This pattern is broadly consistent with the funerary evidence, where the structure of a name seems to be more resistant than the individual elements. The adoption of the tria nomina, which elsewhere comes into use (at least in public contexts) as a badge of citizenship and Roman allegiance is relatively scarce until the mid$2^{\text {nd }}$ century BC, and where it occurs, it is frequently associated with libertine status. Greek script is also fairly robust. Whereas in Etruria and the Veneto, local scripts tend to disappear fairly quickly, to be replaced by inscriptions written in Roman script, even if not with Roman content, Greek persists until well into the Principate and is not overtaken by Latin until the end of the $2^{\text {nd }}$ century $\mathrm{AD}$. We therefore seem to have a broadly similar pattern of funerary inscriptions absorbing different elements of Roman culture at different rates and using these to express localised cultures. The details, however, vary quite a lot; we have the early disappearance of local languages and scripts, and the erosion of indigenous name-forms but the persistence of local names in parts of northern and central Italy as against the persistence of local language and scripts and of local name-forms but the erosion of indigenous 
names in the Greek-speaking parts of the south. In addition, the examination of iconography further indicates that local cultures and traditions persisted, even in use on monuments which show other aspects of Romanitas such as the Ostiala Gallenia stele and the funerary stelai of Naples.

Benelli ${ }^{38}$ argued that the privileged position of Greek in the Roman world means that it cannot validly be considered as part of the same analysis as other pre-Roman Italic languages. However, as the analysis above demonstrates, there is an analogous process of acculturation taking place in the funerary epigraphy of many Greek communities in Italy, although the details and chronology of the process differ. The fact that Greek did indeed enjoy a privileged position means that it survived for far longer than Etruscan or Venetic as a written language used by the elite to record both their public acts and their private funerary monuments. However, the onomastic history of these communities indicates that they were not islands of privileged Hellenism in a rapidly Romanising Italy, but were part of processes of adaptation and cultural hybridization analogous to those taking place in other regions. Clearly there was a considerable impetus amongst the Greek and Oscan elites of Naples, Rhegium, Ancona and most other communities to adopt Roman names, and other symbols of Roman identity feature in the funerary iconography. But all this is set within a framework which retains a large element of local identity - itself a complex mixture of Greek and nonGreek elements.

The considerable amount of variation throughout the Greek and Hellenised areas of Italy suggests that any study of cultural change must take into account the wider spectrum of cultural influences present in each community, rather than viewing the process as an interaction between a single indigenous culture and that of Rome. At Ancona, for instance, there appears to be a smallish sub-group within the elite of the city which retains a largely Greek culture for commemorating their dead, set within a generally Picene then Roman - context. When this Greek or Hellenised funerary culture disappears, it does so suddenly and without the phase of cultural hybridity which characterises many other acculturation processes. Other communities, such as Rhegium and Velia have a period in which Roman and Greek cultures of funerary commemoration co-exist for a time, but disappear gradually during the first half of the $1^{\text {st }}$ century $\mathrm{AD} .{ }^{39}$ At Naples, the same gen-

\footnotetext{
38 Benelli 2001, op. cit. (n. 4), 8.

39 Lomas 1993, op. cit. (n. 9), 177-84.
} 
eral pattern has a greatly elongated chronology, with Greek epigraphic culture persisting into the $2^{\text {nd }}$ century $\mathrm{AD}^{40}$

There are also perceptible differences in response to Roman culture between the various social groups represented, and between various contexts in which inscriptions were set up. Benelli points out that in Etruria, the elite tends to adopt some outward forms of Romanization such as the tria nomina or Romanized forms of Etruscan personal names relatively early but does so in an inconsistent manner and restricts their usage to public contexts. ${ }^{41}$ In contrast, local Etruscan forms are much more likely to continue in use - even by the same families - in a 'private' context. It has been suggested that many families and individuals had a flexible approach to Roman culture, in which adoption of particular Roman symbols in particular contexts was driven by purely pragmatic concerns of personal status and advantage. ${ }^{42}$ Thus the elite may co-opt selected elements of Roman culture as part of a general pattern of internal competition for status. For example, it may be advantageous to present oneself under a Romanised name in a public context such as an honorific or euergetic inscription as a way of demonstrating citizenship and/or familiarity with a particular form of status display, while still using a non-Roman name in more private or informal contexts. These considerations raise some difficult questions of boundaries between public and private, of the cultures and conventions of writing in ancient Italy, and of the status of funerary inscriptions. In a funerary context, attempting a division between private and public spheres is problematic. Funerary stelai have a dual function as a private memorial and representation of personal/family identity on the one hand, and as a public memorial and statement of public persona on the other. ${ }^{43}$ Some of the examples discussed in this paper -including most of those from Naples - were intended for display within the confines of a family mausoleum, access to which would probably have been limited possibly restricted to relatives and/or to access at certain times such as festivals. Others, however, such as the funerary stelai of Padua, may have been set up in a public place as a grave marker. ${ }^{44}$ It is therefore difficult to

${ }^{40}$ Leiwo 1994, op. cit. (n. 29); Miranda 1990 and 1995, opp. citt. (nn. 30 and 35); Lomas 1997-98, op. cit. (n. 29).

${ }^{41}$ Benelli 1994, op. cit. (n. 4), 14-16; id. 2001, op. cit. (n. 4), 10-11.

42 Häussler 2002, op. cit. (n. 4), 72-4.

${ }^{43}$ Hope 2000, op. cit. (n. 3).

${ }^{44}$ Like most of the other so-called 'Stele Patavine', the stele of M' Gallenius and Ostiala Gallenia was not found in its original context. Many of the earlier stelai in this group have a section of rough or unworked stone at their base, which suggests strongly that they were 
generalise on the basis of funerary evidence about whether reception of Roman culture was less widespread in private culture in late republican Italy. If the private/public distinction is accepted, then it does indeed seem that the more public the monument, the more likely it is to be written in Latin. However, we should not lose sight of the fact that many of these grave markers also show a range of other cultural indicators. The tria nomina, for instance, may be relatively infrequent among epitaphs at Naples, but assuming that this reflects usage in private is problematic. The adoption of the full Roman name structure is initially most prominent amongst liberti and therefore may not have had an automatically honorific connotation. ${ }^{45}$ We must also bear in mind the iconography of carved stelai. At both Naples, Ancona and Padua, there are examples of funerary art in which specifically Roman symbols notably the toga - appear in contexts which are otherwise derived largely from local models.

There are also other distinctions between social groups in the adoption of various aspects of Roman funerary culture. Although it is difficult to quantify, it seems probable that there were gender differences in the ways in which Romanised culture was adopted and the uses to which it was put. In the funerary iconography examined for this paper, men seem to be depicted more frequently than women in association with the outward symbols of Romanitas such as the toga, or Romanised names. This may simply reflect the more public role of the elite male and the resulting greater need to adopt and emphasise the symbols of Roman status. However, the matter is not clear-cut, as there are other examples in which men retain non-Roman dress and names, and in which women adopt Roman nomenclature and the status symbols of a Roman matrona. The complexity of evaluating the differing responses to Rome by men and women is highlighted by the pattern of adoption of Romanised names in the Veneto. The onomastic structure of the late Republican Roman name is, typically, praenomen, nomen and (some-

intended to be set upright in the ground. Analogy with funerary practice at Este, where cippi appear to have been set upright outside tombs to mark the entrance, suggests that they may have been displayed in a public location, not within the tomb itself. cf. L. Malnati, 'Il ruolo di Este nella civiltà degli antichi Veneti' in A. Ruta Serafini, ed., Este preromana: una città e $i$ suoi santuari (Treviso 2002). 40-41. The stele of Gallenius and Gallenia does not have this, but it is not entirely clear whether this is because the lower part of the stele was broken off or removed, or because it was designed to be displayed in a different context to the earlier examples. 
times) cognomen for men, while women are principally known by a single name derived from the nomen. ${ }^{46}$ In the Veneto, in contrast, many women appear to have used a personal name, derived from the indigenous onomastics of the region, in addition to a family name derived from the nomen of their father or husband. ${ }^{47}$ In this case, we seem to have an attempt by elite women to display both local and Roman identities.

It seems clear that the funerary monuments of Roman Italy and their inscriptions are a rich source of information about the impact of Rome on Italian society at the personal and familial level. The creation of a Roman or Romanised - culture is not just the result of the adoption of certain norms of Roman public life, or the use of Roman cultural forms in large-scale civic projects such as public building programmes, but of the interaction of Roman and non-Roman culture at the level of everyday life. Individual cultural choices in activities such as dining habits, choice of name, clothes, layout of houses and many other aspects of day-to-day life can be just as important in the interaction of cultures and the development of new ones. ${ }^{48}$ The pattern revealed by the funerary monuments considered in this paper is one of a complex cultural hybridity, in which individuals adopted - and publicly represented themselves as adopting - a range of symbols of Romanitas such as the Latin language, the toga and the Roman tria nomina, but did not do so in a consistent and uniform manner. These aspects of Roman culture continued to co-exist with many aspects of pre-Roman culture as well as completely external cultural influences - for instance, Greek and Oscan culture at Naples, and Celtic, Greek, Etruscan and Venetic cultural influences at Padua. What these monuments represent is not so much the impact of Rome, but rather a process of ongoing cultural dialogue which extends from the public and communal spheres right down to the level of individual cultural choices and identities.

London, January 2004

\footnotetext{
${ }^{45}$ On the possible servile connotations of non-Latin cognomina, and especially Greek cognomina, see I. Kajanto, 'The significance of non-Latin cognomina', Latomus 27 (1968), 517-34.

${ }^{46}$ B. Salway, 'What's in a name? A survey of Roman onomastic practice from c.700 B.C. A.D. 700', Journal of Roman Studies 84 (1994), 124-45.

${ }^{47}$ Untermann 1961, op. cit. (n. 20).

${ }^{48}$ Woolf 1998, op. cit. (n. 2), 7-16. On the cultural implications of personal names, in particular, see S. Hornblower and E. Matthews, Greek Personal Names: Their Value as Evidence (London 2000).
} 


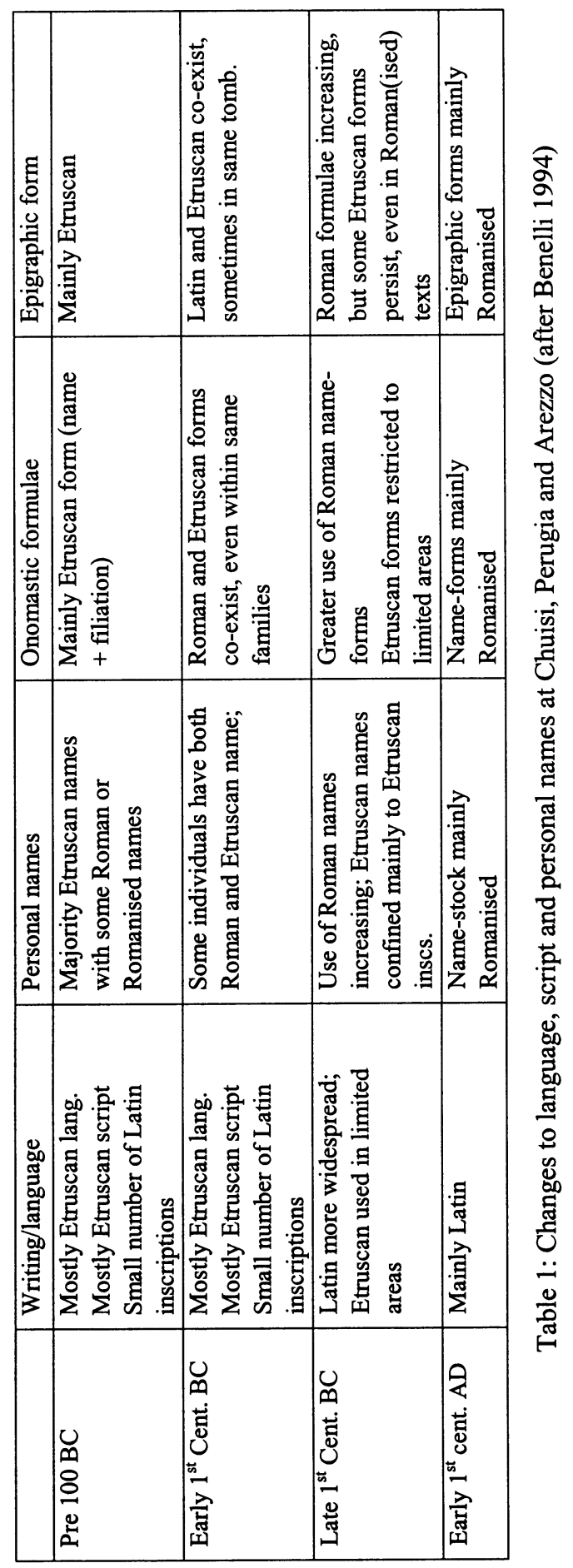



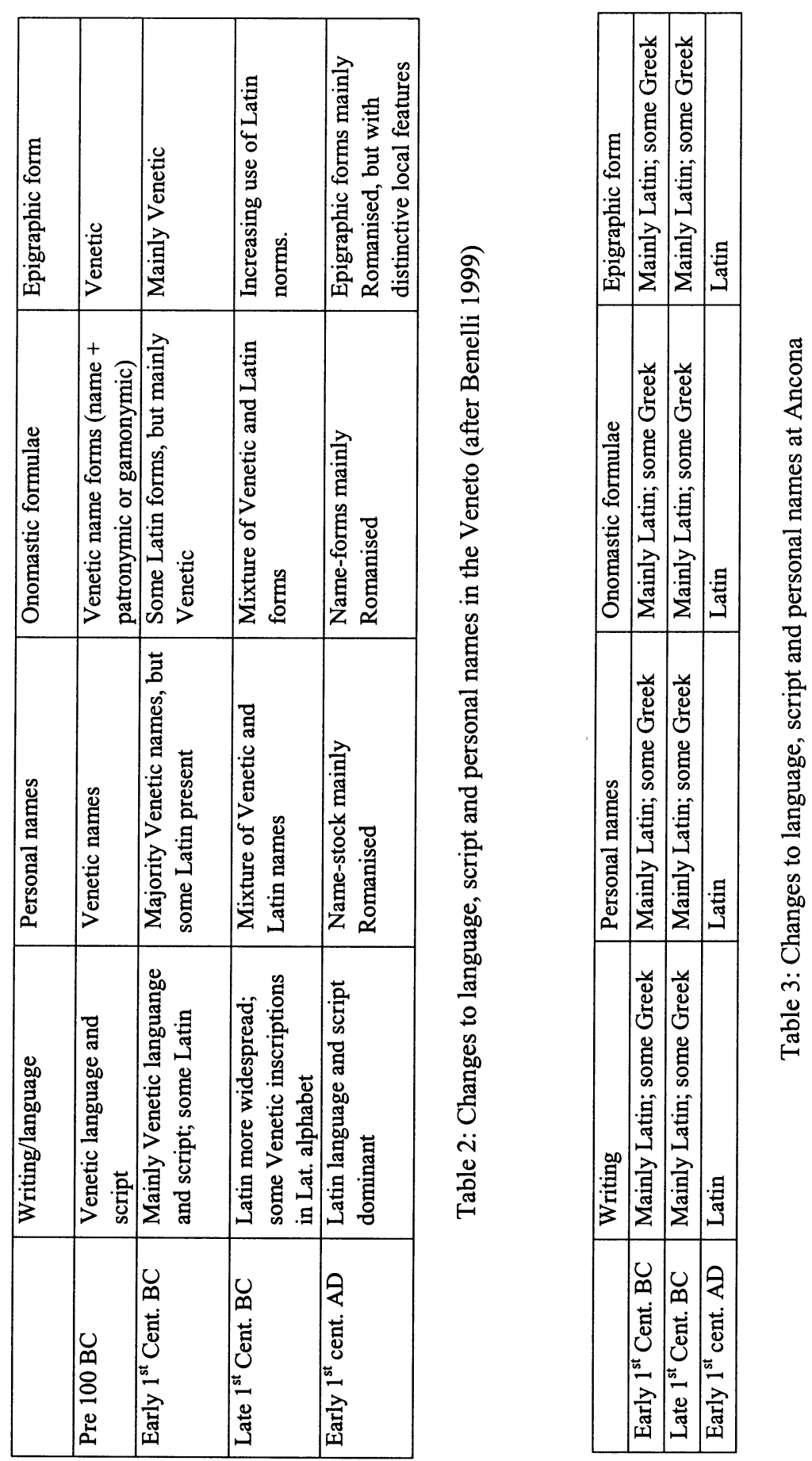


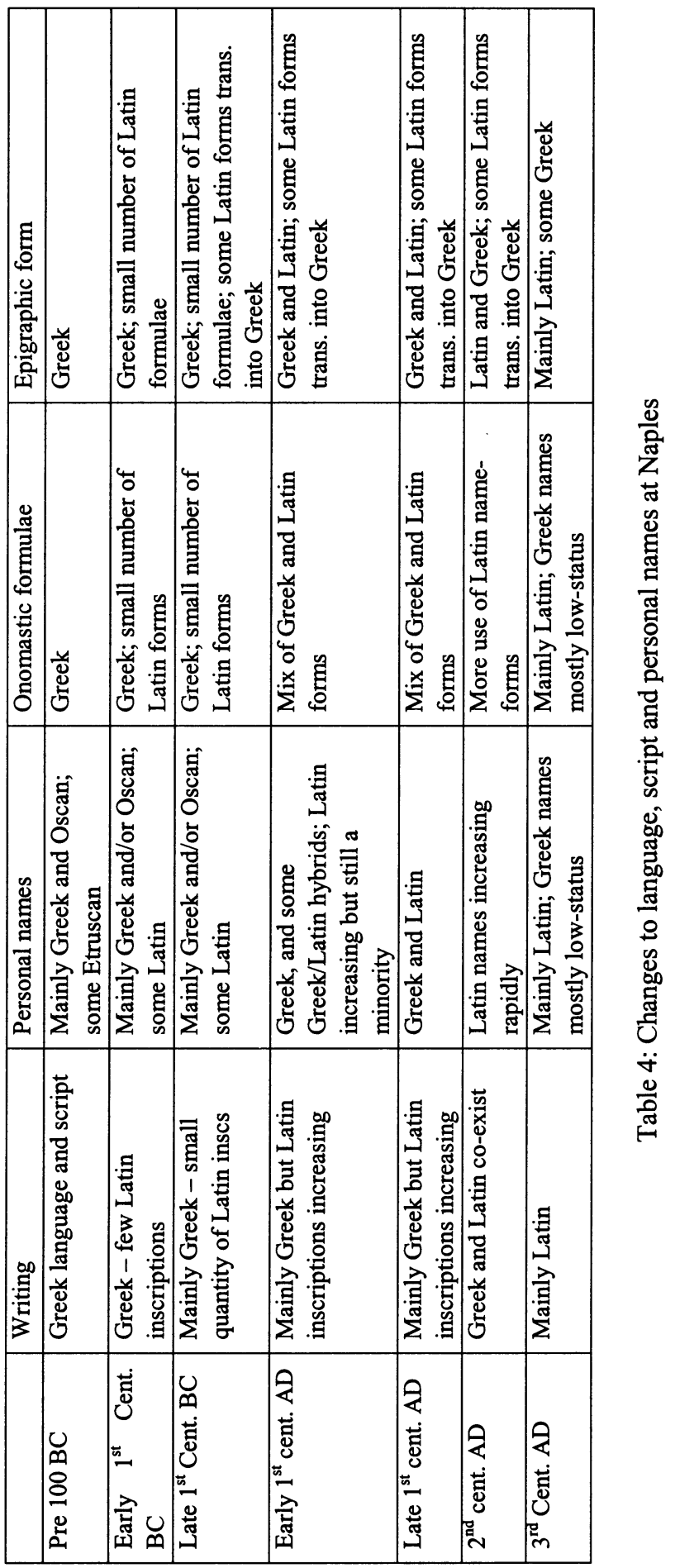

